\title{
Article \\ Dismal Survival in COVID-19 Patients Requiring ECMO as Rescue Therapy after Corticosteroid Failure
}

\author{
Sebastian Voicu ${ }^{1,+}{ }^{\dagger}$ Antoine Goury ${ }^{2,+}$, Thomas Lacoste-Palasset ${ }^{1}$, Isabelle Malissin ${ }^{1}$, Lucie Fanet ${ }^{1}$, \\ Samar Souissi ${ }^{1}$, Julia Busto ${ }^{2}$, Vincent Legros ${ }^{3}$, Laetitia Sutterlin ${ }^{1}$, Giulia Naim ${ }^{1}$, Aymen M'Rad ${ }^{1} \mathbb{D}$, \\ Adrien Pepin-Lehaleur ${ }^{1}$, Nicolas Deye ${ }^{1}$, Bruno Mourvillier ${ }^{2}$ and Bruno Mégarbane ${ }^{1, *,+} \mathbb{C}$
}

1 Department of Medical and Toxicological Critical Care, Lariboisière Hospital, INSERM UMRS-1144, Paris-University, 75010 Paris, France; sebastian.voicu@aphp.fr (S.V.);

thomas.lacoste-palasset@aphp.fr (T.L.-P.); isabelle.malissin@aphp.fr (I.M.); lfanet@chu-reims.fr (L.F.); samar.souissi@gmail.com (S.S.); laetitia.sutterlin@aphp.fr (L.S.); giulia.naim@aphp.fr (G.N.); mrad.aymen@gmail.com (A.M.); Adrien.Pepin-lehaleur@aphp.fr (A.P.-L.); Nicolas.deye@aphp.fr (N.D.)

2 Medical Critical Care Department, Robert Debré University Hospital, 51100 Reims, France; gouryantoine@gmail.com (A.G.); jbusto@chu-reims.fr (J.B.); bmourvillier@chu-reims.fr (B.M.)

3 Surgical Critical Care Department, Maison Blanche University Hospital, 51100 Reims, France; vlegros@chu-reims.fr

* Correspondence: bruno.megarbane@lrb.aphp.fr; Tel.: +33-149958442

+ Sebastian Voicu, Antoine Goury and Bruno Mégarbane contributed equally to this work.

\section{check for}

updates

Citation: Voicu, S.; Goury, A.; Lacoste-Palasset, T.; Malissin, I.;

Fanet, L.; Souissi, S.; Busto, J.; Legros,

V.; Sutterlin, L.; Naim, G.; et al.

Dismal Survival in COVID-19

Patients Requiring ECMO as Rescue Therapy after Corticosteroid Failure. J. Pers. Med. 2021, 11, 1238. https:// doi.org/10.3390/jpm11111238

Academic Editors: Patrick Plaisance and Anthony Chauvin

Received: 24 October 2021

Accepted: 20 November 2021

Published: 22 November 2021

Publisher's Note: MDPI stays neutral with regard to jurisdictional claims in published maps and institutional affiliations.

Copyright: (c) 2021 by the authors. Licensee MDPI, Basel, Switzerland. This article is an open access article distributed under the terms and conditions of the Creative Commons Attribution (CC BY) license (https:// creativecommons.org/licenses/by/ $4.0 /)$.
Abstract: (1) Background: COVID-19 may lead to refractory hypoxemia requiring venovenous extracorporeal membrane oxygenation (ECMO). Survival rate if ECMO is implemented as rescue therapy after corticosteroid failure is unknown. We aimed to investigate if ECMO implemented after failure of the full-recommended 10-day corticosteroid course can improve outcome. (2) Methods: We conducted a three-center cohort study including consecutive dexamethasone-treated COVID19 patients requiring ECMO between 03/2020 and 05/2021. We compared survival at hospital discharge between patients implemented after (ECMO-after group) and before the end of the 10-day dexamethasone course (ECMO-before group). (3) Results: Forty patients (28M/12F; age, 57 years (51-62) (median (25th-75th percentiles)) were included, $28(70 \%)$ in the ECMO-before and $12(30 \%)$ in the ECMO-after group. In the ECMO-before group, $9 / 28$ patients (32\%) received the $6 \mathrm{mg} /$ day dexamethasone regimen versus $12 / 12(100 \%)$ in the ECMO-after group $(p<0.0001)$. The rest of the patients received an alternative dexamethasone regimen consisting of $20 \mathrm{mg} /$ day during 5 days followed by $10 \mathrm{mg} /$ day during 5 days. Patients in the ECMO-before group tended to be younger (57 years (51-59) versus 62 years (57-67), $p=0.053)$. In the ECMO-after group, no patient $(0 \%)$ survived while 12 patients $(43 \%)$ survived in the ECMO-before group $(p=0.007)$. (4) Conclusions: Survival is poor in COVID-19 patients requiring ECMO implemented after the full-recommended 10-day dexamethasone course. Since these patients may have developed a particularly severe presentation, new therapeutic strategies are urgently required.

Keywords: ARDS; COVID-19; corticosteroid; dexamethasone; ECMO; survival

\section{Introduction}

Treatment of acute respiratory distress syndrome (ARDS) induced by coronavirus disease-2019 (COVID-19) relies on supportive intensive care, optimized mechanical ventilation and immunomodulatory treatments including a 10-day course of corticosteroids (based on the RECOVERY study) [1] and/or other immune modulators such as tocilizumab [2]. In extremely severe cases, profound hypoxemia and/or hypercapnia may require venovenous extracorporeal membrane oxygenation (ECMO) $[3,4]$ while awaiting pulmonary recovery. In a large multicenter cohort study, survival of ECMO-treated COVID-19 patients was found to be $\sim 46 \%$ [4]; but less than $30 \%$ of the selected patients received corticosteroids. Surprisingly, in other large published cohorts, corticosteroids were not even accounted 
for. Clinical trials supporting the benefit of corticosteroids included only a minority of COVID-19 patients treated with ECMO early in the clinical course. Interestingly, in the RECOVERY study, only $16 \%$ of the patients were mechanically ventilated and/or treated with ECMO at randomization [1].

Whether the same corticosteroid dose regimen and course duration could be as effective in extremely severe COVID-19 patients as in those without respiratory assistance remains unknown. Although corticosteroids improved overall prognosis, deteriorations were observed, leading to persistently high mortality rate. In patients developing refractory hypoxemia despite corticosteroids, ECMO was an option but survival probability remained unknown.

This is an important issue as patients who deteriorate to the point of requiring ECMO despite the full-recommended 10-day corticosteroid course may present with a more severe disease and higher mortality. We therefore designed this study to investigate if ECMO implemented after corticosteroid failure can improve survival in COVID-19 patients.

\section{Materials and Methods}

\subsection{Study Design and Purposes}

We conducted a retrospective observational cohort study in three University hospitals located in French regions heavily impacted by the pandemic (Paris, Ile de France and Reims, Champagne-Ardennes). The study was performed according to the 2013 Declaration of Helsinki of the World Medical Association regarding medical investigations. It was part of the COVID-ICU and French COVID-19 cohort registries, approved by our institutional ethics committee (IDRCB, 2020-A00256-33; CPP, 11-2020.02.04.68737).

Our main purpose was to compare survival defined as discharge alive from hospital of critically ill COVID-19 patients in relation to corticosteroids and ECMO initiation timing. Survival was compared between patients who required ECMO for ARDS deterioration after a full 10-day corticosteroid course (ECMO-after group) and patients who required ECMO before the last corticosteroid dose on day 10 (ECMO-before group). Our secondary purpose was to identify factors associated with survival including the type of corticosteroid regimen and times from initial symptoms to corticosteroid initiation, from initial symptoms to ECMO implementation, and from intensive care unit (ICU) admission to ECMO implementation.

\subsection{Study Population}

All successive critically ill COVID-19 adults admitted to the three ICUs and treated with corticosteroids and venovenous ECMO were included. Patients who did not require venovenous ECMO during the ICU stay and patients treated with other types of extracorporeal assistance such as veno-arterial or veno-arterio-venous ECMO were not included.

COVID-19 patient management changed during the epidemic according to the available data supporting the effectiveness of proposed treatments. In both centers, dexamethasone was administered in COVID-19 patients with severe ARDS [5] since the beginning of the pandemic, using a dose regimen proposed in ARDS patients [6] consisting in an initial $20 \mathrm{mg}$ /day dose for 5 days followed by a $10 \mathrm{mg}$ /day dose for the 5 subsequent days. After publication of the RECOVERY trial results on dexamethasone (17 July 2020) [1], the administered dose regimen was changed to $6 \mathrm{mg} /$ day for 10 days. Consequently, in the first months of the pandemic, patients received dexamethasone if ARDS was classified as severe according to the Berlin criteria6 after an initial evaluation excluding bacterial infection. After 17 July 2020, dexamethasone were systematically initiated on ICU admission. Patients admitted in the medical wards were also treated with the same regimen and transferred to the ICU if deteriorating despite dexamethasone. Other immunomodulatory therapies were administered at the discretion of physicians in charge. 


\subsection{Ventilation and ECMO Management in the ICU}

Patients were first treated with high-flow oxygen, non-invasive ventilation or a combination of both. If pulmonary function deteriorated further, they received invasive mechanical ventilation with optimized positive end-expiratory pressure, $\leq 6 \mathrm{~mL} / \mathrm{kg}$ tidal volume, $\leq 30 \mathrm{~cm} \mathrm{H}_{2} \mathrm{O}$ or maximum $35 \mathrm{~cm} \mathrm{H}_{2} \mathrm{O}$ plateau pressure if possible and permissive hypercapnia for arterial $\mathrm{pH} \geq 7.25$. Inspired oxygen fraction $\left(\mathrm{FiO}_{2}\right)$ was adjusted to obtain $\mathrm{PaO}_{2} \geq 60 \mathrm{~mm} \mathrm{Hg}$ throughout the entire study period. Prone positioning was performed according to the usual criteria [7]. Nitric oxide and almitrine were administered for persistent hypoxemia according to physicians in charge. If severe hypoxemia and/or hypercapnia and/or respiratory acidosis persisted despite these interventions, ECMO was considered as rescue therapy. Indications of ECMO therapy were assessed by the ICU team, considering the degree of hypoxemia as suggested previously [8], respiratory acidosis, plateau pressure, advanced age, general health status, frailty, presence of debilitating disease and advanced directives if available. Thus, decision to implement ECMO in the present study was based on the usual clinical practice criteria and was not influenced by the corticosteroid treatment.

ECMO was implemented by ICU physicians using the Seldinger technique for vessel cannulation. After ECMO implementation, the patients received optimized supportive care and ventilator settings were adjusted to maintain $\mathrm{PaO}_{2} \geq 60 \mathrm{~mm} \mathrm{Hg}$ and $\mathrm{PaCO}_{2}$ in the normal range if possible, with high positive end-expiratory pressure, tidal volume of $\leq 6 \mathrm{~mL} / \mathrm{kg}$ of ideal body weight, and respiratory rate of $\leq 20 / \mathrm{min}$.

\subsection{Data Collection}

Data were collected retrospectively from electronic medical records. We collected the main demographic, laboratory, ventilation, corticosteroid and immunomodulatory treatment, and outcome data. Outcome was recorded as alive if the patient was discharged alive from hospital. The Sepsis-related Organ Failure Assessment (SOFA) score was calculated on admission [9]. In patients who required ECMO after a full 10-day dexamethasone course, a daily $\mathrm{PaO}_{2} / \mathrm{FiO}_{2}$ ratio was recorded from the first dose until ECMO implementation to describe its time-course pattern.

\subsection{Statistical Analysis}

Results are presented as medians (25th-75th percentiles) for quantitative parameters and percentages for qualitative parameters. Data were compared using Fischer's exacttests for categorical data and Mann-Whitney tests for numerical variables. $\mathrm{PaO}_{2} / \mathrm{FiO}_{2}$ ratios were compared using Friedman tests for paired samples. Parameters were compared between survivors versus non-survivors and univariate logistic regressions were performed to determine parameters associated with survival. Due to the limited sample size, a multivariable analysis of predictors of survival was not performed. Statistical analyses were performed using $\mathrm{R}$ statistical software version 3.6.3. Two-sided $p$-values $<0.05$ were considered significant.

\section{Results}

\subsection{Patient Characteristics}

During the study period, 512 critically ill COVID-19 patients were managed in the two ICUs including 47 patients treated with ECMO. Seven patients were not included in the study, since six of them did not receive any corticosteroid treatment and one was treated with veno-arterio-venous ECMO. Therefore, forty patients (28M/12F; age, 58 years (53-62); body mass index, $31 \mathrm{~kg} / \mathrm{m}^{2}$ (27-35); past hypertension, 13/40 (36\%); diabetes mellitus, 13/40 (36\%)) were included (Figure 1), 28 (70\%) in the ECMO-before group and $12(30 \%)$ in the ECMO-after group. Patient characteristics are represented in Table 1. 


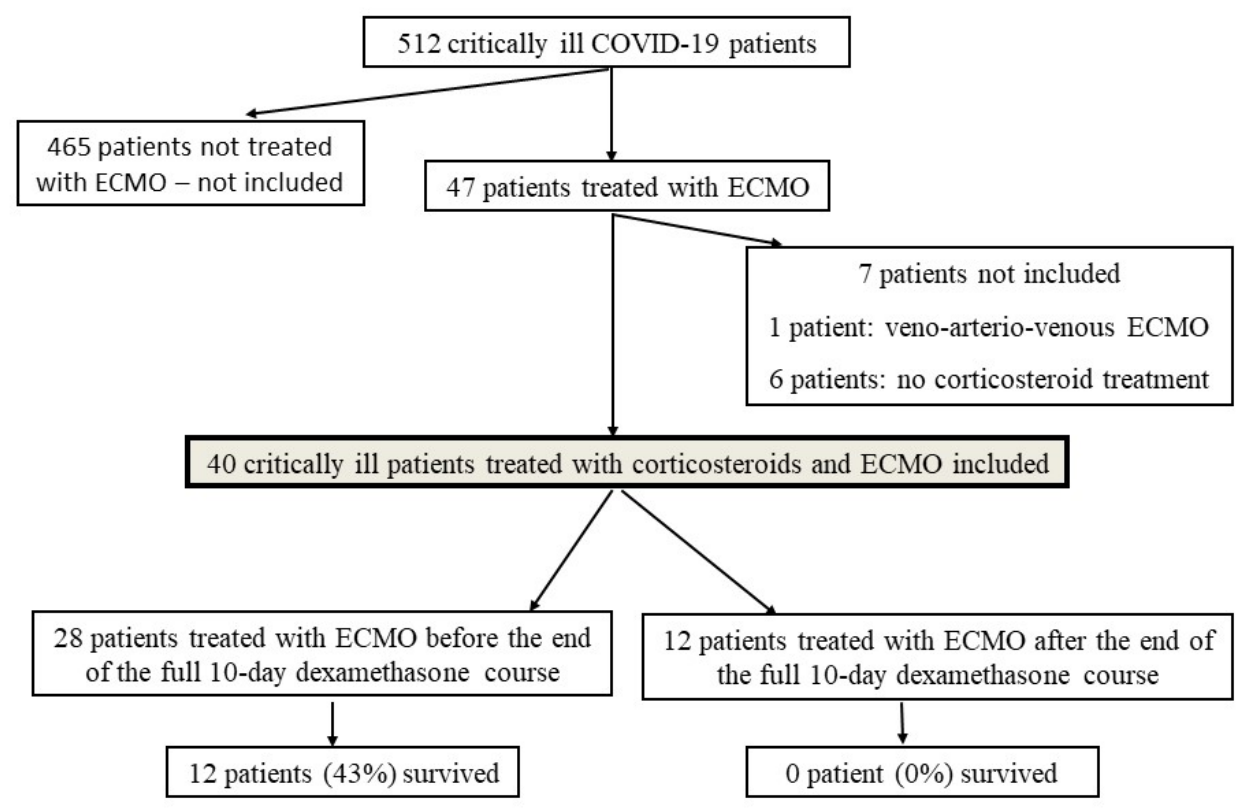

Figure 1. Chart flow.

Table 1. Clinical characteristics on intensive care unit admission.

\begin{tabular}{|c|c|c|c|c|}
\hline Parameters * & $\begin{array}{l}\text { All Patients } \\
\quad(N=40)\end{array}$ & $\begin{array}{c}\text { ECMO before/during } \\
\text { the 10-Day } \\
\text { Dexamethasone } \\
\text { Course } \\
(\mathrm{N}=28)\end{array}$ & $\begin{array}{c}\text { ECMO } \\
\text { after } \\
\text { the 10-Day } \\
\text { Dexamethasone Course } \\
(\mathrm{N}=12)\end{array}$ & $p$-Value \\
\hline Age (years) & $57(51-62)$ & $57(51-59)$ & $62(57-67)$ & 0.053 \\
\hline Male gender, N (\%) & $30(75)$ & $22(79)$ & $8(67)$ & 0.46 \\
\hline Body mass index $\left(\mathrm{kg} / \mathrm{m}^{2}\right)$ & $31(28-35)$ & $32(28-35)$ & $30(27-32)$ & 0.38 \\
\hline History of hypertension, N (\%) & $16(40)$ & $9(32)$ & $7(58)$ & 0.17 \\
\hline Diabetes mellitus, N (\%) & $16(40)$ & $9(32)$ & $7(58)$ & 0.17 \\
\hline Ischemic heart disease, $\mathrm{N}(\%)$ & $3(8)$ & $2(7)$ & $1(8)$ & 1.0 \\
\hline History of heart failure, N (\%) & $1(3)$ & $1(4)$ & $0(0)$ & 1.0 \\
\hline Long-term anticoagulation, N (\%) & $2(5)$ & $1(4)$ & $1(8)$ & 0.52 \\
\hline Long-term aspirin treatment, $\mathrm{N}(\%)$ & $6(15)$ & $3(11)$ & $3(25)$ & 0.34 \\
\hline $\mathrm{PaO}_{2} / \mathrm{FiO}_{2}(\mathrm{~mm} \mathrm{Hg})$ & $84(71-136)$ & $79(61-111)$ & $93(76-158)$ & 0.36 \\
\hline SOFA score on admission & $8(4-12)$ & $9(6-13)$ & $5(3-6)$ & 0.02 \\
\hline
\end{tabular}

${ }^{*}$ Data are expressed as median (25th-75th percentiles) or percentages. ECMO, extracorporeal membrane oxygenation; SOFA, Sepsis-related Organ Failure Assessment.

Baseline parameters did not differ between the two groups except for the SOFA score on admission, which was lower in the ECMO-after group (5 (3-6) versus 9 (6-13), $p=0.02$ ). There was a tendency to older age in the ECMO-after group (62 years (57-66) versus 57 years (51-59); $p=0.053)$. Laboratory parameters did not significantly differ between the two groups (Table 2). 
Table 2. Parameters at ECMO implementation.

\begin{tabular}{|c|c|c|c|c|}
\hline Parameters * & $\begin{array}{l}\text { All Patients } \\
\quad(N=40)\end{array}$ & $\begin{array}{c}\text { ECMO before/during } \\
\text { the 10-Day } \\
\text { Dexamethasone } \\
\text { Course } \\
(\mathrm{N}=28)\end{array}$ & $\begin{array}{c}\text { ECMO } \\
\text { after } \\
\text { the } 10 \text {-Day } \\
\text { Dexamethasone Course } \\
(\mathrm{N}=12)\end{array}$ & $p$-Value \\
\hline Serum creatinine $(\mu \mathrm{mol} / \mathrm{L})$ & $116(64-265)$ & $152(71-283)$ & $92(61-139)$ & 0.14 \\
\hline $\begin{array}{l}\text { Serum alanine aminotransferase } \\
\text { (IU/L) }\end{array}$ & $38(24-80)$ & $38(26-66)$ & $44(22-92)$ & 0.95 \\
\hline Blood lactate (mmol/L) & $1.5(1.2-2.8)$ & $1.5(1.3-2.9)$ & $1.6(1.2-2.2)$ & 0.81 \\
\hline C-reactive protein $(\mathrm{mg} / \mathrm{L})$ & $155(94-264)$ & $155(97-222)$ & $177(56-306)$ & 0.83 \\
\hline Procalcitonin $(\mu \mathrm{g} / \mathrm{L})$ & $1.40(0.2-3.14)$ & $1.25(0.62-2.85)$ & $2.19(0.19-5.49)$ & 0.95 \\
\hline Fibrinogen $(\mathrm{g} / \mathrm{L})$ & $6.0(4.8-7.6)$ & $5.8(4.4-7.1)$ & $6.3(5.4-8.9)$ & 0.18 \\
\hline D-dimer (ng/mL) & 3195 (1858-6208) & $2940(1735-3550)$ & $5750(2975-16,310)$ & 0.09 \\
\hline $\mathrm{PaO}_{2} / \mathrm{FiO}_{2}(\mathrm{~mm} \mathrm{Hg})$ & $56(48-66)$ & $55(48-66)$ & $56(53-67)$ & 0.58 \\
\hline $\mathrm{PaCO}_{2}(\mathrm{mmHg})$ & $58(47-67)$ & $56(45-65)$ & $59(48-69)$ & 0.55 \\
\hline Arterial pH & $7.31(7.23-7.37)$ & $7.32(7.25-7.38)$ & $7.27(7.20-7.34)$ & 0.23 \\
\hline Shock, N (\%) & $36(90)$ & $25(89)$ & $11(92)$ & 1.0 \\
\hline $\begin{array}{l}\text { Renal replacement therapy, } \\
\text { N (\%) }\end{array}$ & $20(50)$ & $14(50)$ & $6(50)$ & 1.0 \\
\hline $\begin{array}{l}\text { Time from first symptoms to } \\
\text { ECMO (days) }\end{array}$ & $13(10-17)$ & $12(10-14)$ & $19(16-28)$ & 0.0002 \\
\hline Length of ICU stay (days) & $31(19-46)$ & $30(17-46)$ & $37(22-45)$ & 0.42 \\
\hline Length of hospital stay (days) & $39(22-59)$ & $37(21-62)$ & $39(25-47)$ & 0.64 \\
\hline \multirow{3}{*}{\multicolumn{5}{|c|}{$\begin{array}{l}\text { * Data are expressed as median (percentiles 25th-75th) or percentages. ECMO, extracorporeal membrane oxygenation; ICU, intensive } \\
\text { care unit. } \\
\begin{array}{l}\text { 3.2. Dexamethasone and Other Immunomodulatory Treatments } \\
\text { All patients received dexamethasone. The } 6 \mathrm{mg} / \text { day dose regimen was administered } \\
\text { to } 9(32 \%) \text { in the ECMO-before group versus } 12(100 \%) \text { in the ECMO-after group }(p<0.0001 ; \\
\text { Table } 3) \text {. Dexamethasone was initiated } 7 \text { days }(6-7) \text { after the first symptoms in the ECMO- } \\
\text { after group versus } 12 \text { days (8-15) in the ECMO-before group }(p=0.003) \text {. Tocilizumab was } \\
\text { administered in eight patients and hydroxychloroquine/azithromycin in five patients. }\end{array}\end{array}$}} \\
\hline & & & & \\
\hline & & & & \\
\hline Parameters * & $\begin{array}{l}\text { All Patients } \\
\qquad(\mathrm{N}=40)\end{array}$ & $\begin{array}{l}\text { ECMO before/during } \\
\text { the 10-Day } \\
\text { Dexamethasone Course } \\
(\mathrm{N}=28)\end{array}$ & $\begin{array}{c}\text { ECMO } \\
\text { after } \\
\text { the 10-Day } \\
\text { Dexamethasone Course } \\
(\mathrm{N}=12)\end{array}$ & $p$-Value \\
\hline Survival, N (\%) & $12(30)$ & $12(43)$ & $0(0)$ & 0.007 \\
\hline Dexamethasone treatment, N (\%) & 40 (100) & $28(100)$ & $12(100)$ & 1.0 \\
\hline $\begin{array}{c}\text { Dexamethasone } 6 \mathrm{mg} / \text { day } \\
\text { regimen, } \mathrm{N}(\%)\end{array}$ & $21(53)$ & $9(32)$ & $12(100)$ & $<0.0001$ \\
\hline $\begin{array}{c}\text { Dexamethasone } 20 / 1 \mathrm{mg} / \text { day } \\
\text { regimen, } \mathrm{N}(\%)\end{array}$ & $19(47)$ & $19(78)$ & $0(0)$ & $<0.0001$ \\
\hline $\begin{array}{l}\text { Time from first symptoms to } \\
\text { dexamethasone (days) }\end{array}$ & $9(7-13)$ & $12(8-15)$ & $7(6-7)$ & 0.003 \\
\hline
\end{tabular}


Table 3. Cont.

\begin{tabular}{|c|c|c|c|c|}
\hline Parameters * & $\begin{array}{l}\text { All Patients } \\
\qquad(\mathrm{N}=40)\end{array}$ & $\begin{array}{l}\text { ECMO before/during } \\
\text { the 10-Day } \\
\text { Dexamethasone Course } \\
\qquad(\mathrm{N}=28)\end{array}$ & $\begin{array}{c}\text { ECMO } \\
\text { after } \\
\text { the 10-Day } \\
\text { Dexamethasone Course } \\
(\mathrm{N}=12)\end{array}$ & $p$-Value \\
\hline Tocilizumab treatment, N (\%) & $8(20)$ & $4(14)$ & $4(33)$ & 0.21 \\
\hline $\begin{array}{l}\text { Number of prone sessions } \\
\text { before ECMO }\end{array}$ & $3(2-4)$ & $3(2-4)$ & $3(2-5)$ & 0.75 \\
\hline Inspired tidal volume (mL) & $352(335-406)$ & $360(343-400)$ & $350(300-391)$ & 0.49 \\
\hline Plateau pressure $\left(\mathrm{cm} \mathrm{H}_{2} \mathrm{O}\right)$ & $30(28-32)$ & $29(25-30)$ & $32(29-34)$ & 0.013 \\
\hline $\begin{array}{l}\text { Positive end-expiratory } \\
\text { pressure }\left(\mathrm{cm} \mathrm{H}_{2} \mathrm{O}\right)\end{array}$ & $12(10-14)$ & $12(10-14)$ & $12(10-14)$ & 0.65 \\
\hline Static compliance $\left(\mathrm{mL} / \mathrm{cm} \mathrm{H}_{2} \mathrm{O}\right)$ & $22(16-29)$ & $25(21-30)$ & $16(13-19)$ & 0.02 \\
\hline Respiratory rate (cycle/min) & $30(28-34)$ & $29(27-32)$ & $33(32-35)$ & 0.03 \\
\hline $\begin{array}{l}\text { Total duration of mechanical } \\
\text { ventilation (days) }\end{array}$ & $28(16-35)$ & $26(16-36)$ & $30(19-36)$ & 0.82 \\
\hline $\begin{array}{l}\text { Time from ICU admission to } \\
\text { ECMO (days) }\end{array}$ & $7(4-9)$ & $5(2-7)$ & $12(10-19)$ & $<0.0001$ \\
\hline $\begin{array}{l}\text { Time from intubation to } \\
\text { ECMO (days) }\end{array}$ & $4(1-6)$ & $3(1-5)$ & $7(2-11)$ & 0.04 \\
\hline ECMO duration (days) & $14(7-26)$ & $13(6-21)$ & $26(11-31)$ & 0.20 \\
\hline
\end{tabular}

* Data are expressed as median (25th-75th percentiles) or percentages. ECMO, extracorporeal membrane oxygenation; ICU, intensive care unit.

\subsection{ECMO Treatment and Correlates of Survival}

$\mathrm{PaO}_{2} / \mathrm{FiO}_{2}$ ratio on optimized mechanical ventilation at $\mathrm{ECMO}$ initiation was $56 \mathrm{mmHg}$ (48-66). Inhaled nitric oxide was administered at cannulation in 27 patients $(75 \%)$ and almitrine in 15 patients (33\%) without significant differences between groups. ECMO was initiated 3 days (1-5) and 7 days (2-11) after tracheal intubation in the ECMO-before versus ECMO-after group $(p=0.04)$. ECMO was initiated earlier during the clinical course in the ECMO-before compared to the ECMO-after group (12 days (10-14) versus 19 days (16-28) since the first symptoms, $p=0.0002$; Table 3). ECMO treatment lasted for 18 days (14-26).

In the ECMO-before group, $12(43 \%)$ survived while in the ECMO-after group, none $(0 \%)$ survived $(p=0.007)$. Death cause was septic shock in 14 patients $(35 \%)$, multiorgan failure without documented infection in 9 patients $(23 \%)$, thrombosis or hemorrhage in 4 patients $(10 \%)$ and persistent hypoxemia in one $(2 \%)$. Based on univariate analyses, parameters significantly associated with survival were the time from ICU admission to $\mathrm{ECMO}$, and time from intubation to $\mathrm{ECMO}$, age, arterial $\mathrm{pH}$ at cannulation, plateau pressure and $6 \mathrm{mg} /$ day dexamethasone regimen (Tables 4 and 5).

Table 4. Comparison of main characteristics between survivors and non-survivors.

\begin{tabular}{cccc}
\hline Parameters $^{*}$ & $\begin{array}{c}\text { Survivors } \\
\mathbf{( N = 1 2 )}\end{array}$ & Non-Survivors (N = 28) & $\boldsymbol{p}$-Value \\
\hline Age (years) & $51(43-56)$ & $60(57-64)$ & 0.0006 \\
\hline SOFA score on admission & $9(4-11)$ & $7(5-12)$ & 0.84 \\
\hline Time from first symptom to ECMO (days) & $12(12-14)$ & $14(10-17)$ & 0.31 \\
\hline Time from ICU admission to ECMO (days) & $4(2-6)$ & $7(5-11)$ & 0.017 \\
\hline Time from intubation to ECMO (days) & $3(0-4)$ & $5(2-7)$ & 0.03 \\
\hline
\end{tabular}


Table 4. Cont.

\begin{tabular}{|c|c|c|c|}
\hline Parameters * & $\begin{array}{c}\text { Survivors } \\
(\mathrm{N}=12)\end{array}$ & Non-Survivors $(\mathrm{N}=28)$ & $p$-Value \\
\hline Time from first symptom to dexamethasone (days) & $13(7-15)$ & $9(6-10)$ & 0.07 \\
\hline Serum creatinine $(\mu \mathrm{mol} / \mathrm{L})$ & $112(54-196)$ & $116(78-272)$ & 0.53 \\
\hline Renal replacement therapy, N (\%) & $3(25)$ & $17(61)$ & 0.08 \\
\hline Blood lactate (mmol/L) & $1.4(1.2-2.0)$ & $1.6(1.2-2.8)$ & 0.56 \\
\hline $\mathrm{PaO}_{2} / \mathrm{FiO}_{2}$ at cannulation $(\mathrm{mm} \mathrm{Hg})$ & $55(45-61)$ & $56(48-68)$ & 0.43 \\
\hline Presence of shock, N (\%) & $10(83)$ & $26(93)$ & 0.57 \\
\hline Arterial $\mathrm{pH}$ at cannulation & $7.37(7.34-7.45)$ & $7.27(7.20-7.33)$ & 0.002 \\
\hline Plateau pressure $\left(\mathrm{cmH}_{2} \mathrm{O}\right)$ & $26(21-30)$ & $30(29-33)$ & 0.015 \\
\hline Static compliance $\left(\mathrm{ml} / \mathrm{cmH}_{2} \mathrm{O}\right)$ & $27(20-30)$ & $21(15-25)$ & 0.11 \\
\hline Positive end-expiratory pressure $\left(\mathrm{cmH}_{2} \mathrm{O}\right)$ & $12(10-14)$ & $12(10-14)$ & 0.95 \\
\hline Dexamethasone 6mg/day regimen, N (\%) & $3(25)$ & $18(64)$ & 0.038 \\
\hline ECMO after at least 10-day dexamethasone, N (\%) & $0(0)$ & $12(43)$ & 0.007 \\
\hline
\end{tabular}

${ }^{*}$ Data are expressed as median (percentiles 25th-75th) or percentages. ECMO, extracorporeal membrane oxygenation; ICU, intensive care unit.

Table 5. Parameters associated with survival in univariate analyses.

\begin{tabular}{cccc}
\hline Parameters & Odds Ratio $(\mathrm{CI}) *$ & $\begin{array}{c}\text { Area under the Curve of the } \\
\text { Model (CI) }\end{array}$ & $\boldsymbol{p}$-Value \\
\hline Age & $0.855(0.764-0.957)$ & $0.844(0.694-0.939)$ & 0.0005 \\
\hline pH at cannulation & $1.97 \times 10^{6}\left(44.600-87.3 \times 10^{9}\right)$ & $0.854(0.696-0.949)$ & 0.0008 \\
\hline Time from ICU admission to ECMO & $0.796(0.642-0.986)$ & $0.740(0.577-0.865)$ & 0.007 \\
\hline Plateau pressure & $0.762(0.601-0.951)$ & $0.786(0.606-0.911)$ & 0.005 \\
\hline Time from intubation to ECMO & $0.759(0.575-1.002)$ & $0.717(0.553-0.848)$ & 0.019 \\
\hline Dexamethasone 6mg/day regimen & $0.1852(0.041-0.845)$ & $0.696(0.531-0.832)$ & 0.021 \\
\hline
\end{tabular}

* An odds ratio $>1$ represents a positive association while an odds ratio $<1$ a negative association between a variable and survival. CI,

95\%-confidence interval; ECMO, extracorporeal membrane oxygenation; ICU, intensive care unit.

\subsection{Time-Course of the $\mathrm{PaO}_{2} / \mathrm{FiO}_{2}$ Ratio in the ECMO-after Group}

The time-course of the $\mathrm{PaO}_{2} / \mathrm{FiO}_{2}$ ratio is shown in Figures 2 and 3. In some patients, $\mathrm{PaO}_{2} / \mathrm{FiO}_{2}$ did not improve significantly until ECMO initiation while in others, the ratio increased to as high as $200 \mathrm{mmHg}$ and decreased before ECMO initiation. On ECMO initiation, a significant decrease in $\mathrm{PaO}_{2} / \mathrm{FiO}_{2}$ ratio was observed but no such significant decrease was observed in the days preceding ECMO initiation (Figure 3). In seven patients $(58 \%)$, positive bronchial aspirates were documented $48 \mathrm{~h}$ before or after ECMO implementation and may have been the reason for $\mathrm{PaO}_{2} / \mathrm{FiO}_{2}$ deterioration. Among the seven patients with positive bronchial aspirates, five required ECMO particularly late during the clinical course, day 4 or later after the end of dexamethasone treatment (Figure 2). 


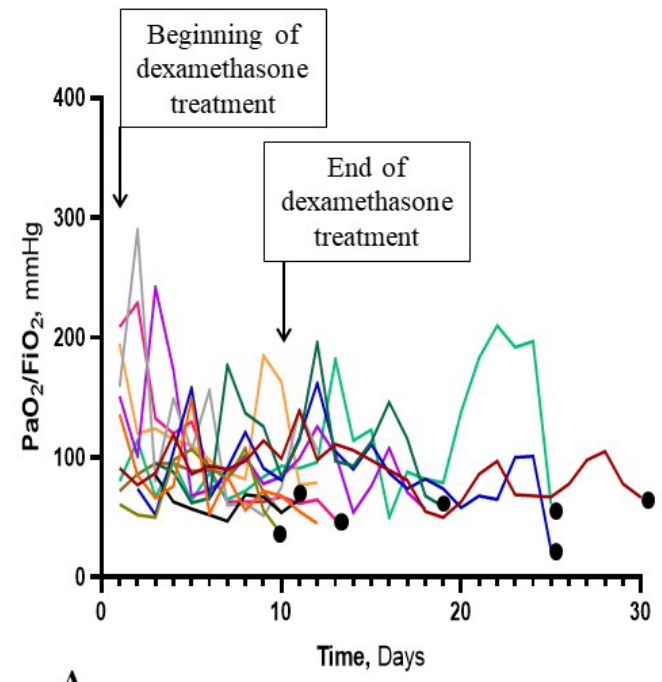

A

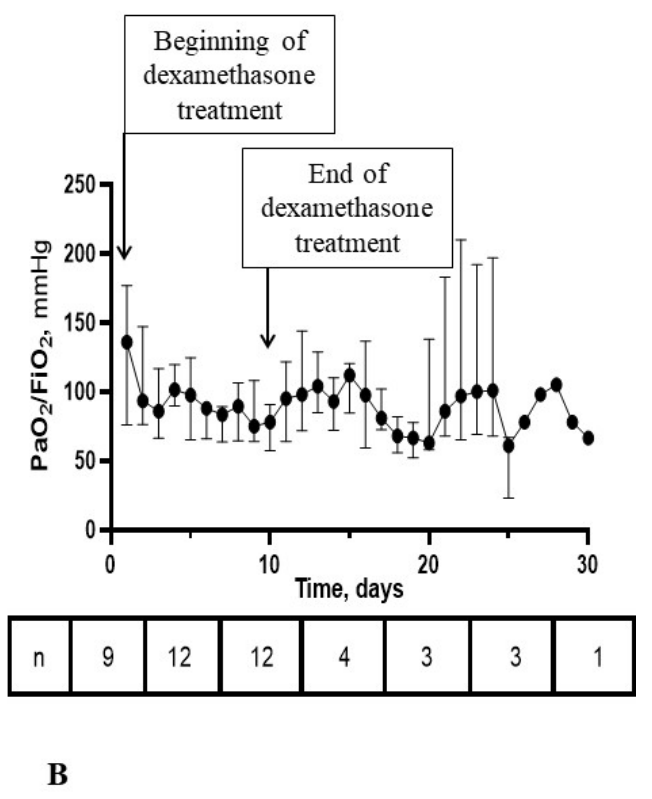

B

Figure 2. Individual and median $\mathrm{PaO}_{2} / \mathrm{FiO}_{2}$ ratios from corticosteroid initiation to ECMO implementation in the 12 patients included in the ECMO-after group. Panel (A) represents $\mathrm{PaO}_{2} / \mathrm{FiO}_{2}$ curves in individual patients. Data are missing in 3 patients on day 1. Curves end the day of ECMO implementation. Black dots identify patients with a diagnosis of bacterial pneumonia 48h before or after the day of ECMO initiation. Panel (B) represents median values and interquartile ranges as vertical bars. Numbers at the bottom represent the number of patients with available data. After day 10, the number of patients decreased as ECMO was initiated and only $\mathrm{PaO}_{2} / \mathrm{FiO}_{2}$ ratios in ECMO-free patients were represented. The beginning and the end of corticosteroid treatment are shown by the corresponding arrows in both panels.
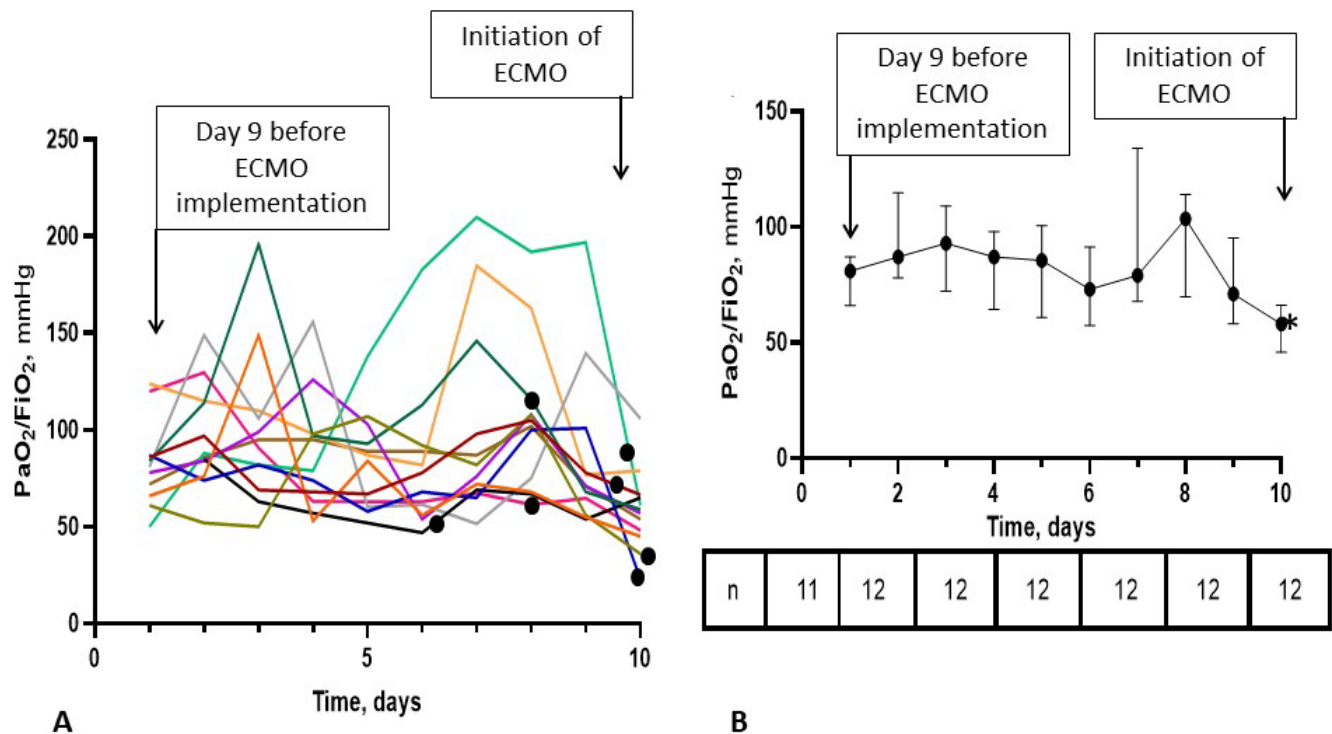

Figure 3. Individual and median $\mathrm{PaO}_{2} / \mathrm{FiO}_{2}$ ratios during the 10 days before ECMO implementation in the 12 patients included in the ECMO-after group. Panel (A) represents $\mathrm{PaO}_{2} / \mathrm{FiO}_{2}$ ratios of individual patients during the 9 days preceding ECMO initiation and the day of ECMO initiation (corresponding arrows). Data is missing in one patient on day 9 before ECMO initiation. Black dots in panel A represent patients with a diagnosis of bacterial pneumonia $48 \mathrm{~h}$ before or after the day of ECMO initiation. These were placed at different time points to avoid overlap with other curves. Panel (B) represents median $\mathrm{PaO}_{2} / \mathrm{FiO}_{2}$ ratios and interquartile ranges as vertical bars. ${ }^{*}$ Significant difference in day10 (days of ECMO implementation) compared to day 2, 3, 4, 7, 8 by Freedman tests for paired samples. 


\section{Discussion}

We evaluated the survival rate at hospital discharge in patients requiring ECMO for aggravating ARDS during or after the recommended 10-day dexamethasone course in critically ill COVID-19 patients. The major finding of our study is that survival was null in patients in whom ECMO was required after the end of the full dexamethasone course (Figure 1). Although corticosteroid allowed a major improvement in COVID-19 patient outcome [10], management of patients who fail to improve under corticosteroids is still challenging, as shown in our study. In the ECMO-after group, $\mathrm{PaO}_{2} / \mathrm{FiO}_{2}$ ratio curves clearly showed no improvement in some patients despite $6 \mathrm{mg}$ dexamethasone but marked improvement in others to values up to $200 \mathrm{~mm} \mathrm{Hg}$, followed by subsequent decrease as shown in Figures 2 and 3. Our observations suggest that some patients did not respond to dexamethasone while others responded initially then deteriorated due to superinfections or COVID-19-related inflammation relapse. Thus, low $\mathrm{PaO}_{2} / \mathrm{FiO}_{2}$ ratios during and after the end of the corticosteroid course may herald a prolonged COVID19 course and/or an incomplete response to corticosteroids, favoring hospital-related complications including superinfections. In most of our patients, once the recommended 10-day dexamethasone treatment ended, patients received essentially supportive care, close monitoring and treatment of complications. Despite effective treatment in patients with documented superinfections, pulmonary function did not improve and patients could not be weaned from ECMO. In the five patients without documented pulmonary infections before and after ECMO implementation, deterioration most likely occurred due to the underlying COVID-19. To date, no new treatment strategy has been proven useful in this setting. Some authors suggested that higher corticosteroid doses [11] and/or high-dose methylprednisolone boluses [12,13] may be effective as rescue therapy and that duration of treatment may have to be adapted to the disease length and severity, instead of being administered on a one size fits all basis [14]. Interestingly, a very recently published randomized control studies showed that $12 \mathrm{mg} /$ day compared with $6 \mathrm{mg} /$ day dexamethasone did not result in significantly more days alive without life support at 28 days among patients with COVID-19 and severe hypoxemia [15]. However, the authors acknowledged that the trial might have been underpowered. Therefore, it remains to be determined whether other immune modulators may be useful in these very severe patients. The dismal survival in the ECMO-after group also raises the question of futility of ECMO if no new therapeutic options become available, especially in periods of pandemic when healthcare resources become scarce.

Previous studies showed that age and shorter time from intubation to ECMO implementation are associated with survival [4], suggesting that beyond 7 days of intubation, survival is null [16]. In the ECMO-after group, $50 \%$ of our patients received ECMO earlier than 7 days after intubation. Therefore, we consider that increased mortality rate is not exclusively due to the time from intubation to ECMO implementation although this time may have contributed. In a large cohort, age and $\mathrm{pH}$ at cannulation were determined as major prognostic factors of survival [17]; but these parameters did not significantly differ in our study between the ECMO-before and ECMO-after groups. Interestingly, requiring ECMO after the end of the recommended full 10-day corticosteroid course was not associated with mortality in univariate analysis in our cohort. Therefore, this characteristic cannot be considered as a primary independent predictor of mortality in the overall population, but should be regarded as a major characteristic identifying a particularly severe patient subgroup with extremely high mortality.

In our patients, we reported an overall survival rate of $30 \%$ versus $46 \%$ in the study by Lebreton et al. [4]. Differences may be explained by an older age in our patients (58 years (53-62) versus 52 years (45-58)) and a lower $\mathrm{PaO}_{2} / \mathrm{FiO}_{2}$ ratio at cannulation ( $57 \mathrm{~mm} \mathrm{Hg}$ (48-68) versus $61 \mathrm{~mm} \mathrm{Hg}(54-70)$ ) [4]. Moreover, the very high mortality in the ECMO-after group accounted for the high overall mortality while survival rate in the ECMO-before group was $43 \%$, similar to the $46 \%$ rate noted in the study by Lebreton et al. [4]. Recently, based on the international Extracorporeal Life Support Organization Registry, mortality 
after ECMO for patients with COVID-19 was shown to have worsened during 2020 [18]. ECMO after 1 May 2020 had a higher likelihood of treatment-refractory disease despite similar risk factors, and centres with less experience providing ECMO support for COVID19 patients were more likely to have a higher mortality rate. These observations clearly suggested that prognosis in ECMO-treated COVID-19 patients is multifactorial and does not only depend on patient-related criteria but on various patient-independent parameters related to the pandemic. Surprisingly, the relation between failure of ECMO rescue therapy and the duration of corticosteroid administered before ECMO implementation was not investigated in this registry-based study as we did here.

None of our patients achieved the conditions requested for lung transplantation by the thoracic surgeons of our university hospital group. Lung transplant in COVID-19 patients is a controversial issue, despite recently reported excellent results as option of last resort [19]. Whether some selected COVID-19 patients with end-stage lung disease might be candidates for lung transplant from compromised donors, remains also to be investigated.

Our study has limitations. Patients in the ECMO-before group were admitted late after symptom onsets (12 days (8-15)) in comparison to patients in the ECMO-after group (7 days $(6-7) ; p=0.003)$. The delay from intubation to ECMO was also significantly different between groups ( 3 days $(1-5)$ versus 7 days $(2-11) ; p=0.04)$. Thus, we cannot assume that all characteristics of the two compared groups were the same, meaning that patients in the ECMO-after group may have missed the window of the optimal treatment opportunity explaining the worse survival in this group. However, at the ECMO implementation, no remarkable cardiac dysfunction nor differences in organ failure, vasopressor infusion and other treatment use were observed between the two groups. Interestingly, according to the SOFA score on admission, which significantly differed between the two patients groups, survival rate would have been expected to be lower in the ECMO-before than in the ECMO-after group, contrasting with what was observed ( $43 \%$ versus $0 \%$, respectively). Therefore, our finding clearly suggests that ECMO requirement after the completion of the recommended full 10-day corticosteroid course identified a particularly severe patient group with extremely high mortality rate. The small sample size precluded any multivariate analysis to determine the factors independently associated with mortality. In univariate analyses, major prognostic factors known as prognosticators in COVID-19 patients requiring ECMO (age, arterial $\mathrm{pH}$ at ECMO implementation, time from intubation to ECMO implementation) were identified by our analysis as well as other factors, which are useful to generate hypotheses for future research, such as the negative correlation with survival of the time between ICU admission and ECMO implementation and of the $6 \mathrm{mg}$ dexamethasone dose regimen. Thus, prolonged treatment with corticosteroids and/or higher doses may be tested in the future, in patients who require ECMO after the end of the initial ten-day corticosteroid course. Timing of ECMO implementation in our study may have been later than what was suggested, as $\mathrm{PaO}_{2} / \mathrm{FiO}_{2}$ of $80 \mathrm{~mm} \mathrm{Hg}$ was put forth as cutoff [8], while our patients received ECMO at later stages, due to logistical issues related to the pandemic. Therefore, we cannot exclude that the outcome may have been different if the ECMO was initiated earlier in both groups, although there is no available randomized data supporting this hypothesis in COVID-19 patients or ARDS patients in general. For instance, although the fact that non-survivors appeared to be markedly older was predictable, we cannot exclude that age delayed decision of ECMO initiation due to resource rationing in the initial days of the pandemic. Finally, we identified a COVID-19 population with an extremely high risk of death despite management based on current knowledge on ARDS treatment including ECMO rescue therapy; however, we could not determine the exact causes of severity and the optimal therapeutic strategies to improve survival. Therefore, our study is a call for urgently needed research for new therapeutic strategies in COVID-19 patients with refractory ARDS. 


\section{Conclusions}

Our study showed a dismal survival in COVID-19 patients who required ECMO after the end of the recommended 10-day dexamethasone course, which calls for new therapeutic strategies to improve outcome. Patients with advanced lung injury from COVID-19 may benefit from extreme supportive measures, such as ECMO, if considered early during the clinical course. Therefore, future studies that may help understanding the best ECMO management of these complex patients are needed.

Author Contributions: Conceptualization, S.V., A.G. and B.M. (Bruno Mégarbane); methodology, S.V. and B.M. (Bruno Mégarbane); software, S.V. and A.G.; validation, S.V., A.G. and B.M. (Bruno Mégarbane); formal analysis, S.V. and B.M. (Bruno Mégarbane); patient management, S.V., A.G., T.L.-P., I.M., L.F., S.S., J.B., V.L., L.S., G.N., A.M., A.P.-L., N.D., B.M. (Bruno Mourvillier) and B.M. (Bruno Mégarbane); investigation and data collection, S.V., A.G., T.L.-P., I.M., L.F., S.S., J.B., V.L., L.S., G.N., A.M., A.P.-L., N.D., B.M. (Bruno Mourvillier) and B.M. (Bruno Mégarbane); data curation, S.V. and B.M. (Bruno Mégarbane); writing-original draft preparation, S.V.; writing-review and editing, B.M. (Bruno Mégarbane); supervision, B.M. (Bruno Mégarbane). All authors have read and agreed to the published version of the manuscript.

Funding: This research received no external funding.

Institutional Review Board Statement: The study was conducted according to the guidelines of the Declaration of Helsinki. The study was part of the COVID-ICU and French COVID-19 cohort registries and approved by our institutional Ethics Committee (IDRCB, 2020-A00256-33; CPP, 11 2020.02.04.68737)

Informed Consent Statement: Patient written consent was waived due to the non-interventional study design that did not modify existing diagnostic or therapeutic strategies. Only the nonopposition of the patient or his legal representative was collected in accordance with the ethical standards of French legislation.

Data Availability Statement: Mégarbane have full access to all data and takes responsibility for the data integrity and its analysis accuracy. Data supporting reported results can be obtained from the corresponding author if reasonably justified.

Acknowledgments: The authors would like to thank Alison Good (Scotland, UK) for her helpful review of the manuscript.

Conflicts of Interest: The authors declare no conflict of interest.

\section{References}

1. Recovery Collaborative Group; Horby, P.; Lim, W.S.; Emberson, J.R.; Mafham, M.; Bell, J.L.; Linsell, L.; Staplin, N.; Brightling, C.; Ustianowski, A.; et al. Dexamethasone in Hospitalized Patients with Covid-19. N. Engl. J. Med. 2021, 384, 693-704. [PubMed]

2. REMAP-CAP Investigators; Gordon, A.C.; Mouncey, P.R.; Al-Beidh, F.; Rowan, K.M.; Nichol, A.D.; Arabi, Y.M.; Annane, D.; Beane, A.; van Bentum-Puijk, W.; et al. Interleukin-6 Receptor Antagonists in Critically Ill Patients with Covid-19. N. Engl. J. Med. 2021, 384, 1491-1502. [PubMed]

3. Schmidt, M.; Hajage, D.; Lebreton, G.; Monsel, A.; Voiriot, G.; Levy, D.; Baron, E.; Beurton, A.; Chommeloux, J.; Meng, P.; et al. Extracorporeal membrane oxygenation for severe acute respiratory distress syndrome associated with COVID-19: A retrospective cohort study. Lancet Respir. Med. 2020, 8, 1121-1131. [CrossRef]

4. Lebreton, G.; Schmidt, M.; Ponnaiah, M.; Folliguet, T.; Para, M.; Guihaire, J.; Lansac, E.; Sage, E.; Cholley, B.; Mégarbane, B.; et al. Extracorporeal membrane oxygenation network organisation and clinical outcomes during the COVID-19 pandemic in Greater Paris, France: A multicentre cohort study. Lancet Respir. Med. 2021, 9, 851-862. [CrossRef]

5. ARDS Definition Task Force; Ranieri, V.M.; Rubenfeld, G.D.; Thompson, B.T.; Ferguson, N.D.; Caldwell, E.; Fan, E.; Camporota, L.; Slutsky, A.S. Acute respiratory distress syndrome: The Berlin Definition. JAMA 2012, 307, 2526-2533. [PubMed]

6. Villar, J.; Ferrando, C.; Martínez, D.; Ambrós, A.; Muñoz, T.; Soler, J.A.; Aguilar, G.; Alba, F.; González-Higueras, E.; Conesa, L.A.; et al. Dexamethasone treatment for the acute respiratory distress syndrome: A multicentre, randomised controlled trial. Lancet Respir. Med. 2020, 8, 267-276. [CrossRef]

7. Guérin, C.; Reignier, J.; Richard, J.C.; Beuret, P.; Gacouin, A.; Boulain, T.; Mercier, E.; Badet, M.; Mercat, A.; Baudin, O.; et al. Prone positioning in severe acute respiratory distress syndrome. N. Engl. J. Med. 2013, 368, 2159-2168. [CrossRef] [PubMed]

8. Combes, A.; Hajage, D.; Capellier, G.; Demoule, A.; Lavoué, S.; Guervilly, C.; Da Silva, D.; Zafrani, L.; Tirot, P.; Veber, B.; et al. Extracorporeal Membrane Oxygenation for Severe Acute Respiratory Distress Syndrome. N. Engl. J. Med. 2018, 378, 1965-1975. [CrossRef] [PubMed] 
9. Vincent, J.L.; Moreno, R.; Takala, J.; Willatts, S.; De Mendonça, A.; Bruining, H.; Reinhart, C.K.; Suter, P.M.; Thijs, L.G. The SOFA (Sepsis-related Organ Failure Assessment) score to describe organ dysfunction/failure. Intensive Care Med. 1996, 22, 707-710. [CrossRef] [PubMed]

10. Cano, E.J.; Fonseca Fuentes, X.; Corsini Campioli, C.; O’Horo, J.C.; Abu Saleh, O.; Odeyemi, Y.; Yadav, H.; Temesgen, Z. Impact of Corticosteroids in Coronavirus Disease 2019 Outcomes: Systematic Review and Meta-analysis. Chest 2021, 159, 1019-1040. [CrossRef] [PubMed]

11. López Zúñiga, M.Á.; Moreno-Moral, A.; Ocaña-Granados, A.; Padilla-Moreno, F.A.; Castillo-Fernández, A.M.; GuillamónFernández, D.; Ramírez-Sánchez, C.; Sanchez-Palop, M.; Martínez-Colmenero, J.; Pimentel-Villar, M.A.; et al. High-dose corticosteroid pulse therapy increases the survival rate in COVID-19 patients at risk of hyper-inflammatory response. PLoS ONE 2021, 16, e0243964. [CrossRef]

12. So, C.; Ro, S.; Murakami, M.; Imai, R.; Jinta, T. High-dose, short-term corticosteroids for ARDS caused by COVID-19: A case series. Respirol. Case Rep. 2020, 8, e00596. [CrossRef] [PubMed]

13. Pinzón, M.A.; Ortiz, S.; Holguín, H.; Betancur, J.F.; Cardona Arango, D.; Laniado, H.; Arias Arias, C.; Muñoz, B.; Quiceno, J.; Jaramillo, D.; et al. Dexamethasone vs methylprednisolone high dose for Covid-19 pneumonia. PLoS ONE 2021, 16, e0252057. [CrossRef] [PubMed]

14. Meyerowitz, E.A.; Sen, P.; Schoenfeld, S.R.; Neilan, T.G.; Frigault, M.J.; Stone, J.H.; Kim, A.Y.; Mansour, M.K. Immunomodulation as Treatment for Severe COVID-19: A systematic review of current modalities and future directions. Clin. Infect. Dis. 2020, 72, e1130-e1143. [CrossRef] [PubMed]

15. COVID STEROID 2 Trial Group; Munch, M.W.; Myatra, S.N.; Vijayaraghavan, B.K.T.; Saseedharan, S.; Benfield, T.; Wahlin, R.R.; Rasmussen, B.S.; Andreasen, A.S.; Poulsen, L.M.; et al. Effect of $12 \mathrm{mg}$ vs $6 \mathrm{mg}$ of Dexamethasone on the Number of Days Alive Without Life Support in Adults With COVID-19 and Severe Hypoxemia: The COVID STEROID 2 Randomized Trial. JAMA 2021, in press.

16. Giraud, R.; Legouis, D.; Assouline, B.; De Charriere, A.; Decosterd, D.; Brunner, M.E.; Moret-Bochatay, M.; Fumeaux, T.; Bendjelid, K. Timing of VV-ECMO therapy implementation influences prognosis of COVID-19 patients. Physiol. Rep. 2021, 9 , e14715. [CrossRef] [PubMed]

17. Biancari, F.; Mariscalco, G.; Dalén, M.; Settembre, N.; Welp, H.; Perrotti, A.; Wiebe, K.; Leo, E.; Loforte, A.; Chocron, S.; et al. Six-Month Survival After Extracorporeal Membrane Oxygenation for Severe COVID-19. J. Cardiothorac. Vasc. Anesth. 2021, 35, 1999-2006. [CrossRef] [PubMed]

18. Barbaro, R.P.; MacLaren, G.; Boonstra, P.S.; Combes, A.; Agerstrand, C.; Annich, G.; Diaz, R.; Fan, E.; Hryniewicz, K.; Lorusso, R.; et al. Extracorporeal membrane oxygenation for COVID-19: Evolving outcomes from the international Extracorporeal Life Support Organization Registry. Lancet 2021, 398, 1230-1238. [CrossRef]

19. Walter, K. Lung Transplants for COVID-19-The Option of Last Resort. JAMA 2021, in press. [CrossRef] [PubMed] 